\title{
Take politics off the table: A study of Italian youth's self-managed dairy restriction and healthy consumerism
}

Social Science Information

I-25

(C) The Author(s) 2020

Article reuse guidelines: sagepub.com/journals-permissions DOI: I0.I I77/05390I8420973596 journals.sagepub.com/home/ssi

@SAGE

\author{
Niccolo Morelli \\ Catholic University of the Sacred Hearth, Italy.
}

\section{Tommaso Vitale}

Sciences Po, France

\begin{abstract}
The last 20 years have been characterized by very different dynamics: massive reduction of milk and, to a lesser extent, dairy consumption; fewer positive attitudes towards milk; no reclaims for affordable, public dairy production; the development of a large conversation about the presumed risks associated with the intake of lactose; and semantic battles on non-dairy 'milk' alternatives. These new attitudes haven't been systematically studied. We explore here the links between milk/dairy consumption, health concerns, and trust in medical expertise. Through an online survey of highly educated youth in Italy $(\mathrm{N}=378)$ we have investigated: milk and dairy consumption; attitudes towards items carried out by vegan movements; attitudes towards medical expertise and trust in counseling by general practitioners. Results show that anti-speciesist and vegan movements are very little known among consumers. Data display very limited impact of the ideas and concepts of antimilk movements within our sample. The results highlight that milk consumption shrinking is due to health concern and an unfavorable perception of dangerous consequences in lactose intake, and additionally to a general distrust towards medical expertise and evidence-based arguments. Indeed, we observe a tendency to self-diagnose intolerance/ allergies, questioning the role of physicians and medical knowledge in advising for dietary choices among highly educated youth. The analysis of the patterns of consumption and motives clearly shows that health considerations, not politics, are behind the Italian youth's dairy restrictions. Healthy consumerism emerges as a concept fitting better than political consumerism for interpreting our results.
\end{abstract}

\section{Corresponding author:}

Tommaso Vitale, Sciences Po, Centre d'études européennes et de politique comparée, 28, rue des Saints-

Pères, Paris, 75337, France.

Email: tommaso.vitale@sciencespo.fr 


\section{Keywords}

cultural sociology, ethical consumerism, Italy, milk, youth culture

\section{Résumé}

Les vingt dernières années ont été traversées par différentes dynamiques : la réduction massive de la consommation de lait et, dans une moindre mesure, de produits laitiers ; des attitudes de plus en plus négatives à l'égard du lait ; aucune revendication pour une production abordable et publique du lait ; le développement d'une vaste discussion à propos des risques qui seraient associés à la consommation de lactose ; et des batailles sémantiques autour des alternatives que constituent les « laits ॥ non laitiers. Ces nouvelles attitudes n'ont pas été systématiquement étudiées. Nous explorons ici les liens entre la consommation de lait et de produits laitiers, les préoccupations en matière de santé et la confiance dans l'expertise médicale. À partir d'un sondage en ligne auprès des populations jeunes et éduquées en Italie $(N=378)$, nous avons analysé : la consommation de lait et de produits laitiers, les attitudes envers les arguments portés par les mouvements végans, les attitudes envers l'expertise médicale et la confiance dans les conseils dispensés par les médecins. Les résultats ont mis en évidence que les mouvements antispécistes et végans sont assez peu connus des consommateurs. Les données ont montré que les idées et les concepts des mouvements anti-lait avaient un impact limité sur notre échantillon. Les résultats soulignent que la réduction de la consommation de lait est due à des préoccupations en matière de santé et à une perception défavorable des apports en lactose et, additionnellement, à une méfiance générale envers l'expertise médicale et les arguments fondés sur des preuves. En effet, nous observons une tendance à l'auto-diagnostic pour les intolérances et les allergies, une tendance chez les populations jeunes et éduquées qui mettent en doute le rôle des médecins et du savoir médical dans l'accompagnement diététique. L'analyse des schémas de consommation et de motivation montre clairement que des considérations liées à la santé, et non à des opinions politiques, sont derrière les restrictions des jeunes italiens en matière de produits laitiers. Un consumérisme orienté vers la recherche d'une meilleure santé a émergé, un concept qui fonctionne mieux que celui de consumérisme politique pour interpréter nos résultats.

\section{Mots-clés}

consumérisme éthique, culture des jeunes, Italie, lait, sociologie culturelle

\section{From milk as social investment to milk as risk}

The consumption of dairy products is a very interesting sociological phenomenon. It is an iconic food in Western societies specifically during childhood, although, the consumption of cow's milk is quite recent in human history as a widespread food substitute for breast milk (DuPuis, 2002). In the post-war years, in regimes of alimentary scarcity, milk became a real object of worship because it was considered a food product with high nutritional content (Mendelson, 2008). Milk was the object of a massive investment by public health reformers, left wingers, and social democrats all over Europe during the 1950s and 1960s. 
Regulatory policies for improving milk's quality and reducing its price have been introduced in almost all European countries. While Britain and the Netherlands have had nationally subsidized school milk programs since the 1930s, in other West European countries, this kind of policy instrument started after World War II due to frequent promotion by UNICEF (Inaudi, 2018). The development of microbiology - applied to nutrition issues regarding the contribution of proteins and vitamins for physical health at different stages of life - magnifies the justification to increase milk and dairy consumption beyond the upper-middle class to middle-to-lower social classes. During the Marshall Plan to reconstruct Western Europe, milk was presented as the 'perfect food' (Inaudi, 2018: 151) and was sustained by the Milk Conservation Program - a scheme for sustaining the territorial spread of independent milk-processing plants. Technological change contributed to greater milk production and expanded milk-drinking campaigns. The public investment in both the International Milk Genomic Consortium (IMGC) and public agencies in charge of producing and distributing affordable milk has been massive. One objective involved improving milk's taste by moving from the poorly soluble roller skimmed type (often rejected by children for its 'nauseating' taste) to more palatable, pasteurized, whole fullcream powdered milk (see DuPuis, 2002). This was not just a European concern; Dolly Daftary (2019), for example, has proven that, in India, a complex process of socialization has resulted in positive attitudes towards milk, political mobilization for milk decommodification, and the same preference for the taste of milk: it 'had to be learned; it was acquired and cultivated, not a part of habitus' (2019: 84). Moreover, in China, milk is becoming an iconic food especially for babies and families try to afford to buy European milk brands for better milk quality and as a status symbol (Sabban, 2014).

For European States, fresh, high-quality, affordable, 'public' milk has been a major achievement and, in this context, especially cities have been participating in a public health promotion strategy. As a redistributive policy to advantage working classes, it was considered a 'social investment' for new generations (in the sense of Morel et al., 2012) and a 'health soft infrastructure' for families and elderly people.

At the end of World War II, in Europe, adults started consuming milk for breakfast (Le Pape \& Plessz, 2017). Precisely, the time of breakfast changed during that period, moving from a break after a couple of hours of work to a meal scheduled before the business day (Doxa-Aidepi, 2015). In Italy, in particular, the current breakfast mode emerged at the end of the 1940s 'when Italians substituted the consumption of cold leftovers of the evening meal (for example, pasta or polenta with herring or cheese) with stale bread soaked in milk' (Harman, 2018). At that moment, milk consumption was around $48 \mathrm{~kg}$ per person per year, alongside heavy territorial inequalities, and a protein deficit of $50 \%$ occurred at the national level, reaching $70 \%$ in Central Italy, $84 \%$ in the South, and $85 \%$ on the islands (Inaudi, 2018: 152). For both Christian democrats and communists as well as the first feminist movements, milk was a symbol of social struggle for progress, welfare, and positive development regardless of political cleavages (Tosi \& Vitale, 2008).

Milk consumption rose to 72 liters per person in 1973 (Zamagni, 1998). In the 1970s and 1980s, milk was still considered a main source of wellness and a fundamental commodity - such as water and bread - that had to be de-commodified and made available outside market regulation (Pagliai, 2010). This was a global trend and was not exclusively specific to Western countries; in India, during the 1970 s, a massive wave of 
cooperative-sector dairy production aimed to stably include milk in the 'national diet' (NDDB, 1977: 3) and surely provide 'urban consumers permanent access to milk at stable prices at any time' (Terhal, 1987: 167), which included 'reducing the cost of milk' (Daftary, 2019: 84) 'to benefit consumers' (Bardhan \& Huria, 1987: 95-96). In Latin America, due to improvements in milk production, in the 1990's milk consumption was 112 liters per person (Delgado, 2003), while in Africa, thanks to international aids and a better microbiological quality of milk, consumption raised from 35 to 40 liters between 1990 and 2004 (Kamana et al., 2014).

Looking at the Italian case, affordable milk was part of a larger agenda of territorial welfare benefits reclaimed by unions when negotiating with public authorities together with public transports, health services, and sporting facilities for the working class (Polizzi et al., 2013). Indeed, milk was considered necessary, 'good', an element for kids and adults, determinant for a flourishing life, constituent of an ordinary diet, and thus an object of political investment and collective action. Promoting milk and dairy consumption was a public health instrument not only for its socio-medical value, but also for its implicit socialization effect; it would acculturate and become accustomed to being 'eat[en] rationally', as the important policy-maker Lodovico Montini, and brother of the future Pope Paul VI, stated (Montini, 1957).

By contrast, the last 20 years have been characterized by very different dynamics: (1) massive reduction of milk and, to a lesser extent, dairy consumption; (2) fewer positive attitudes towards milk; (3) no reclaims for affordable, fresh, high-quality, public dairy production; (4) the development of a large conversation about the presumed risks associated with the intake of lactose; and (5) semantic battles on non-dairy 'milk' alternatives (based on soya, rice, oats, almonds, cashews, or hemp).

These new attitudes have been less systematically explored by empirical sociology, even if claimed as a promising topic (Borgerson, 2005). Sociological research has started to explore how new attitudes are providing a demand for a non-dairy milk market expansion (Mouat \& Prince, 2018). In addition, research on the political economy of milk for new-borns has evolved, pushed by waves of massive political criticism by anti-transnational corporations' movements as well as by pro-breastfeeding movements (Kristensen et al., 2011).

Milk consumption shrinking has been slightly investigated by cultural sociology. Some papers have insisted on the link between risk and danger in food consumption, especially in regard to unpasteurized milk in rural areas (Enticott, 2003). Melanie DuPuis (2002) has described the rise of controversies throughout the 1990s over genetically engineered cows and questions about antibiotic residue that have prompted consumers to question whether the milk they drink each day is truly good for them or is instead toxic and unhealthy. We inscribe our work in the tradition of cultural sociology research, contributing to it by exploring the links between milk/dairy consumption, political consumerism/veganism, health concerns, and medical mistrust (Idan et al., 2020). The choice of exploring these links is based on existing literature concerning skepticism towards medical science and expertise (Jones, 2017; Nichols, 2017; Williamson \& Bigman, 2018), as well as youth studies framing new generations attitudes as socialized in a crisis setting marked by individualization and 'presentification' (Leccardi, 2014), and also growing attention to individual freedoms and self-realization (Alteri et al., 2016). 
Our results reveal that negative attitudes towards milk-derived foods are not exclusively related to an increased role of health concerns and an unfavorable perception of dangerous consequences in lactose intake, but additionally to a general mistrust towards medical expertise and evidence-based arguments.

\section{Literature review and hypotheses}

In the five-year period from 2012 to 2016, Italian families reduced their milk consumption by $7 \%$ (Ismea, 2017). This decrease has generally characterized all products of animal origin, but milk has suffered a much more pronounced decline, while only highly digestible milk has not suffered this drop. According to the Ismea-Nielsen Consumer Panel Service data, the animal-origin food curtail is attributable to ethical and/or health issues such as a more pronounced interest in animal welfare, lactose intolerances, and allergies. The generations that have most widely abandoned milk consumption are the younger generations aged up to 35 years. If it is undeniable that there has been a decrease in the consumption of milk and dairy products, especially among the younger generations, then much less evident are the causes that explain this decrease. In fact, the 2018 Eurispes Report found that, in Italy, only $0.9 \%$ of the population is vegan (Eurispes, 2018). The European Food Security Agency, EFSA, has assessed that, even if someone has a lactose deficiency, it is possible for him/her to ingest $240 \mathrm{ml}$ of cow's milk per day (EFSA, 2010). Therefore, veganism and intolerances cannot exclusively explain such a marked drop in consumption.

In Italy, the Penetration Index of dairy products - the percentage of households that consume dairy products at least once a year - is very high (96\%). However, household expenditures in this area of the food market fell to around -250 million euros $(-15.8 \%)$ (Ismea, 2017). This decrease is mainly due to young families and high-income families, thus debunking a possible cause to be found in economic factors. Another important figure is the increase in the sale of lactose-free or soy-based products of $+47 \%$ and $+107 \%$, respectively, but these products still represent a very narrow niche.

In short, average attitudes towards milk consumption seem to have dramatically changed in Western societies. In the past, milk was a fundamental right, an essential and key component of any healthy diet that was promoted by the state, international organizations, local governments, and philanthropic bodies. Today, the withdrawal of public investments in dairy consumption schemes, the decrease in fluid milk consumption as a beverage, a return to breast milk - which is perceived as safer and healthier than cow's milk - and the antispecies criticism against animal exploitation and cattle diseases (Cohen, 2017) all seem to point to a very different structure of citizens' attitudes towards lactose-based food. Surprisingly, this supposed new attitude structure has not been analyzed by population segments. In this section, we will synthetically recall the main empirical results and determine how they converge into several contradictory hypotheses.

Research on milk consumption in social sciences is a longstanding tradition. Peter Atkins (2010) stresses that the field of 'milk studies' has incessantly grown since the beginning of the 1970s. His genealogical study of milk as a commodity, Liquid Materialities (2010), as well as the more recent collection edited by Mathilde Cohen and Yoriko Otomo (2017) explore milk's material, affective, historical, semantic, symbolic, 
and economic relations. In the last 20 years, milk studies have demonstrated their embeddedness in a conundrum of macro-sociological changes, including masculinity crises and moving gender roles, tensions in food sovereignty, climate changes, and the quest for sustainable lifestyles. Far more than mere beverage or food, milk is a metaphor in the more post-structural culturalist approach, a gendered commodity in the interactionist framework, or a legal entity (Wright, 2019).

In other words, milk is a political issue not only due to its political economy of production and price regulation, but also in its consumption patterns. Even the capacity for absorbing lactose has been mobilized by racist white supremacists (DuPuis, 2002; see also Harmon, 2018; Moon, 2018) and questioned by new waves of animalist protest (Bertuzzi, 2018, 2019). These works are important but are based more on the empirical analyses of activist frames and ideological constructions or are directly engaged in political combats; they neither provide evidence on the spread of competing frames in citizens attitudes' nor on the degree of cultural wars' penetration on the fraught political status of milk within the population. From this literature, we draw our first hypothesis: milk consumption depends upon the political meaning conferred to animal exploitation as well as environmental sustainability.

A second stream of research on milk consumption is more interested in the meaning people attribute to consumption choices. The qualitative research of Sidse Schoubye Andersen and Lotte Holm (2018) reveals the relevance of the purity and naturalness (non-processed food) category in consumers' choices. Parents explain why they limit their children's milk consumption 'in response to its perceived non-naturalness and the conflicting messages they had received about milk' (2018: 303), and the authors also insist on the fact that fathers do not make the decision to abandon milk, but they delegate it to the mothers' choice even when they are 'highly involved caregivers' (2018: 303).

A recent study explored consumer preferences for select milk attributes in the USA, showing that the largest preference shares were for price, fat content, and humane handling, with gender and age not statistically different across several consumer segments (Bir et al., 2019). The study's main limit was the absence of any comparison with nonmilk/dairy consumers. Nevertheless, the results are important for finding a specific class of consumer 'balance' between animal welfare aspects and milk's physical characteristics. Moreover, it seems that consumers are becoming more and more aware of the necessity to consider animal welfare. Research conducted between Italy, Sweden, and Great Britain revealed how, especially in Italy and Sweden, more than $50 \%$ of the respondents (1,500 consumers aged between 18 and 80 years weighted by region, sex, age, household, and population size) were fairly or strongly interested in animal welfare when making consumption choices (Mayfield et al., 2007). This segment is distinguished from that of those having large preference shares for price and container size as well as that opting for traditional milk attributes.

Consumers' justifications based on ideas of naturalness are not imperative and do not really shape consistent practices. On the contrary, consumers shielding and protecting themselves from potential harm derived from dangerous food consumption seems to be steady. Carol Morris and colleagues (2019) demonstrate how perceived health benefits motivate the choice to drink non-dairy milk products, and even more how moderate choices of partial and contingent substitutions for dairy milk are based on health claims. 
Existing literature on alternative consumers attitudes have mainly focused on dimensions of advocacy and vegan movements (Bertuzzi, 2020), reducing the attention paid to the issues not related to political contents or identity questions (Veron, 2016). Moreover, these studies have focused on activists and social movements, rather than consumers as a whole. On the opposite side, we believe that it is interesting to understand choices not made with a clear political attitude, trying to understand if new trends in milk and dairy consumption are merely an identity issue or could be driving to a new consumers culture. In particular, we know that vegans show consistency (Turina, 2018) between beliefs and actions and the element of consistency becomes a distinctive point especially to differentiate from vegetarians (Turina, 2019). Our research was designed to explore if youth attitudes and behaviors show elements of consistency, or inconsistency, between beliefs and practices in non-dairy products consumption.

Literature has not explored the relation between consistency and health concerns yet. What we bring here is not only an exploration of this dual relation but broadly of the configuration of consistency (between beliefs and behavior), health concerns and trust in medical authority. The introduction of the concept of trust requires a precise definition and discussion within the sociological debate. Trust here is conceptualized in a Weberian manner, as strictly related to conventional forms of link between individuals, procedures and institutions. Advice and behavioral rules prescribed by mainstream medicine are statutory, submitted by medical agencies' impersonal order, and the persons thereby appointed to exercise authority by this order are obeyed by virtue of their formal status and the conventional nature (Vitale, 2003) of its ordinances and the scientific domain over which they have force. Trust in official medical science and its prescriptions is neither based on the virtue of piety and familiarity with the physician 'appointed by tradition (and bound by it)', nor by any 'charismatic rule' as Max Weber (2019: 342) would say, so to say acquired by virtue of personal trust in revelation, heroism, or exemplary qualities in healing. This is why trust in medicine is a specific form of trust, functional more than just official (Schluchter, 1986) structured by impersonality, confidence in peer-review, respect of meta-analysis and transnational regulatory agencies. It is very institutionalized, related to confidence in State neutrality and externality from interest pressures, and it has a high level of abstraction from personal relations and self-confidence in ego's own knowledge or sensible experience, which was very common among highly educated people (Boltanski, 1968). But it remains closely related to actor's possession and use of knowledge, thus 'it is contingent in large part on one's knowledge resources and their control' (Cicourel, 1999: 185). Indeed, nowadays it requires to be explored empirically again. The hypothesis is that the more and more highly educated people (and especially among the new generations) wish to self-determine themselves, to make decisions for their health in an autonomous way, even in fields that require a lot of knowledge, and without trusting physicians anymore. Emblematic is the case of the movements for raw-milk, which see in milk the perfect 'natural' food, but whose purity they want to consider, and do not accept the scientific analysis that insists on its dangerousness when not pasteurized (Mattozzi \& Piccioni, 2012). They do not mistrust medicine and science but physicians and scientists as human persons exposed to lobbies and interest groups.

The literature on health benefits and danger perception is consistent and usually differs from official guidelines on health (Andersen \& Holm, 2018: 307). Even if there isn't literature on mistrust of medical expertise related to milk and dairy consumption, the rise 
of books and guidelines differing from official ones suggest that people prefer to inform themselves autonomously rather than rely on medical expertise We explore if, and how, this could affect also milk and dairy consumption. Literature reveals that young people manifest a clear intolerance of hierarchies and authority, and growing attention to individual freedoms and self-realization (Alteri et al., 2016). We structured our questionnaire with a second hypothesis on weak trust towards medical expertise.

\section{Data}

\section{Target}

This paper is the result of a study carried out with young people aged under 30 in Italy. The choice of this specific target was motivated by the fact that the drop-in consumption has been observed particularly among newer generations (Nielsen \& Popkin, 2004; Gerrior et al., 1998). We selected the special segment of highly educated youth for our study because they are keener to be attentive and receptive to ethical concerns and challenging lifestyle choices related to political consumerism, as this segment of population is more fascinated by a vegetarian or vegan diet (Allès et al., 2017). This reflects also works that underline the relevance of education to explain who is most influenced by social movements' production of ideas (Bassoli \& Monticelli, 2018; Mayer, 2018; for Italy, specifically, see Biorcio \& Vitale, 2020). On one hand, this sample choice posits many contraindications that a very representative sample easily faces while on the other hand, our sample was designed to look inside a very specific consumer segment, exploring its eventual internal sub-segments.

\section{Preliminary qualitative data: Net-ethnography}

Between October and November 2016, before designing the survey, we collected qualitative data from in-depth interviews with physicians (general practitioners) and a net-ethnography of activists' websites against the production and consumption of milk and dairy products in Italy. Net-ethnography can be defined as a study of the relations created and maintained through computer-mediated social interactions (Bowler, 2010; Kozinets, 2010). As a result of the advent of the World Wide Web, new social actors have had access to a much wider dissemination of contents and theories. Social movements in the field of consumption have been able to contribute to the creation of a sort of informal consumer education (Sandlin, 2007; Armstrong, 2000). Consumerism has become a massive field for social movements' action and generativity that initially trusts the market choices as a crucial leveler for producing change and then combines it with campaigns for new regulatory standards (Micheletti, 2003; Tosi \& Vitale, 2009; Forno, 2018).

We have been stimulated by the part of the literature that claims that the web has contributed to the spread of ideas against milk consumption and how these sites may contribute to the formation of consumer culture. For this reason, we studied the three important Italian websites that criticize the consumption of milk and dairy products: Infolatte, Scienza Vegetariana, and Agire Ora. 
We followed the posts, articles, and discussions in these websites to frame some of the following items included on our survey questionnaire: those related to milk's harmfulness to humans, those that bring attention to animal and environmental advocacy, and those concerning the motives for ceasing the consumption of milk and dairy products.

\section{Preliminary qualitative data: In-depth interviews}

In-depth interviews were administered between October and November 2016 prior to designing the survey in order to collect general practitioners' opinions on the pros and cons of milk and dairy product consumption. We administered 20 interviews in different Italian regions among physicians who were selected with the snowball technique, and each interview lasted around half an hour. We put forward young people's doubts regarding dairy products, physicians' personal opinions regarding milk consumption, and the latter's knowledge of movements against dairy product consumption.

Our objective was not to obtain a representativeness of the doctors' social representations of the contentious milk consumption field; rather, we wanted to grasp doctors' reactions both towards the youth's eventual skepticism about their role and towards milk and dairy consumption in general. Moreover, we asked how they diagnose milk-related and other dairy-related digestion problems as well as what main counsel and advice they give to patients.

\section{Survey sample}

An online survey was designed to understand young people's choices to consume milk and dairy products, their attitudes, and their social representations. The questionnaire collected questions on attitudes towards anti-dairy movements, interest in health and physical well-being, environmental awareness, support for animal welfare, and trust in evidence-based scientific knowledge.

Data were collected online between December 2017 and January 2018, and participants were recruited through a snowball sampling. The sample was not statistically representative, as it over-represents youth with higher education levels. This choice was deliberate, as it allowed us to explore attitudes and behaviors of a segment that was apparently under-analyzed in the last available survey (Ismea, 2017). Our sample is not representative of Italian youth, but rather of its highly scholarized segment.

378 respondents participated in the questionnaire; 270 were women (71\%) and 108 men $(29 \%), 64 \%$ at the age of 25 to 30 years and $46 \%$ at the age of 18 to 24 years. $42 \%$ of the respondents originated from the North, 30\% from the South, and $28 \%$ from Central Italy. Only 19\% claimed they were married or living with a partner - a percentage that corresponds with the Italian average for youth (Istat, 2018). A much smaller number of respondents aged 18 to 34 still lived with their families $(42 \%)$, compared to $63 \%$ of the national population's average for the same age range. These are particularly the young people of the South who, having moved from the South to either Central Italy or the North, found themselves needing to leave their family units. In fact, $37 \%$ of respondents originally from the South lived in the North, while $12 \%$ had moved to Central Italy. 
As we said, we deliberately sampled respondents with higher qualifications than the average population aged 18 to 30 . In fact, $63 \%$ of respondents claimed they at least acquired an undergraduate degree, compared to $18 \%$ of the national Italian average. Practically no respondents (1\%) possessed a lower education qualification (eight years of study), while $36 \%$ possessed merely a high school diploma (13 years of study), compared to the national average's $56 \%$, oversampling those having 16 years of study or more ${ }^{1}$.

\section{The questionnaire}

The questionnaire comprised five sections. In the first section, respondents were asked about their consumption habits, their shopping roles, and what factors they paid particular attention to (e.g., price, origin, brand, ingredients, organic certification, and so on). Subsequently, a second section was dedicated to the consumption/ non-consumption of milk and dairy products. In particular, respondents were asked what dairy products they consumed and why. For those who stopped milk and dairy consumption, in a third section, we investigated the reasons they abandoned such consumption and whether this concerned all or only some dairy products. In particular, they were asked whether their reasons for ceasing consumption were related to physical discomfort or to a certified intolerance or allergy and, most importantly, whether that allergy or intolerance was either diagnosed by a physician (and how) or self-diagnosed.

Afterwards, we deeply interrogated the degree of agreement/disagreement with respect to health-, ethics-, and environment-related issues. These queries were phrased on the basis of both statements collected during our primary net-ethnography on antimilk consumption websites as well as of assertions gathered by the 20 qualitative interviews among practitioners. These items allow inquiry into consumer awareness regarding non-evidence-based information trending in the media as well as demands and (dis)trust in medical expertise. The last section inquired about standard sociodemographic variables.

\section{Patterns of consumption and motives: Health considerations, not politics, are behind the Italian youth's dairy restrictions}

$14 \%$ of respondents claimed they do not habitually consume milk or dairy products. The basket of dairy products provided in the survey included milk, yoghurt, soft/fresh cheese, aged cheese, spreadable cheese, ricotta, butter, and sour cream, and respondents were allowed to add additional items. $71 \%$ of respondents claimed they consume mozzarella at the very least, slightly more than one of two consumers drink milk $(56 \%)$ and eat yoghurt (54\%), 66\% and 65\%, respectively, eat mature and fresh/soft cheeses, while less than one of two consumers snacks on spreadable cheeses $(47 \%)$. The consumption of butter and cream for cooking trailed far behind, at merely $32 \%$ and $22 \%$, respectively. 


\section{We distinguish the following four consumer segments:}

(1) those who do not consume any dairy products $(14 \%)$;

(2) those who consume one or two dairy products $(13 \%)$;

(3) those who consume three or four dairy products $(30 \%)$;

(4) those who consume more than four dairy products $(43 \%)$.

In our sample, milk was not among the top three dairy products consumed. Indeed, it should be noted that $51 \%$ of respondents do not consume milk at all. These respondents are those who do not consume any dairy products in addition to those who eat dairy products other than milk. This percentage is higher than that estimated by Ismea (2017) on a representative sample of the population, demonstrating the younger generation's aversion and the more educated population's knowledge of this specific product.

With regard to the reasons for consuming dairy products, $73 \%$ of respondents attributed the choice to taste, $18 \%$ to habit, while less than one of ten respondents indicated 'different reasons'. Of those who do not consume milk or dairy products, $93 \%$ stopped consuming altogether, while $7 \%$ had never consumed milk or dairy products in their lives. $35 \%$ of non-consumers claimed to have stopped consuming milk and dairy products for medical reasons, while $34 \%$ claimed to have experienced digestive problems but received no medical examination. $13 \%$ claimed they do not appreciate the taste of dairy products, while $9 \%$ stated they do not consume dairy products for ethical reasons.

Respondents were also asked about their dietary regimes. 91\% said they are omnivorous, compared to $6 \%$ claiming vegetarianism and $1 \%$ claiming veganism, while $2 \%$ follow other dietary regimes (e.g., macroprotein diet). Compared to the Eurispes (2017) data on Italians' eating habits, our sample achieved a higher number of vegetarians and a lower number of vegans ( $5 \%$ and 3\%, respectively, in the Eurispes survey).

Crossing the data between diet and motivation, most omnivores essentially do not reflect on the reason for their diets $(76 \%)$, while $19 \%$ claimed they are omnivorous for personal reasons (Table 1). What was observed, on the contrary, is that vegetarians and vegans reflect much more adamantly on their food choices (87\%), compared to only $9 \%$ who claimed they have no particular reason for following their diets. Three of four vegans affirmed that the motivation for their dietary regime was influenced by personal choices.

\section{Explaining change I: A drop in milk and dairy consumption to protect animals and the environment?}

After having described the main patterns of behavior in our sample, we can explore the two main hypotheses that emerge from the literature. As we previously mentioned, the first states that milk consumption depends upon the political meaning conferred to animal exploitation as well as environmental sustainability and veganism. Thus, if the hypothesis is verified, we expect to observe a strong correlation between an ethical concern for animal welfare and sustainability, on one side, and dairy consumption, on the other; ethical concerns would imply a reduction in dairy use.

In order to answer this hypothesis, we identified and proposed two items between the ideas promoted by the websites we analysed in our netnography, including 'Eating 
Table I. Motives for a dietary regime.

\begin{tabular}{|c|c|c|c|c|c|}
\hline \multirow[t]{2}{*}{ Diet } & \multicolumn{5}{|l|}{ Motives } \\
\hline & $\begin{array}{l}\text { No particular } \\
\text { reason }\end{array}$ & $\begin{array}{l}\text { Medical } \\
\text { advice }\end{array}$ & $\begin{array}{l}\text { Personal } \\
\text { reasons }\end{array}$ & Others & $\mathrm{N}$ \\
\hline Omnivore & $76 \%$ & $2 \%$ & $19 \%$ & $3 \%$ & 344 \\
\hline Vegetarian & $9 \%$ & $4 \%$ & $87 \%$ & $0 \%$ & 23 \\
\hline Vegan & $0 \%$ & $0 \%$ & $75 \%$ & $25 \%$ & 4 \\
\hline Others & $43 \%$ & $14 \%$ & $14 \%$ & $29 \%$ & 7 \\
\hline Total & & & & & 378 \\
\hline
\end{tabular}

products of animal origin is unfair' and 'It is necessary to stop consuming milk and dairy products in order to have a lower environmental impact'. Both these items have implications with respect to animal and environmental dimensions.

In our sample, only $19 \%$ of respondents agreed that 'eating products of animal origin is unfair'. Crossing the data between the degree of agreement and the type of milk/dairy consumer, those who do not believe consuming products of animal origin is unfair are mainly large consumers of these dairy products (75\%); however, even among those who do agree, those who consume those products make up the majority (62\%). In other words, although some people do not consider it acceptable to eat products of animal origin, this belief does not affect their consumption habits.

$69 \%$ of respondents agreed that it is necessary to stop consuming milk and dairy products in order to reduce the environmental impact; this attitude is equally distributed among omnivore and vegetarians/vegans. However, even in this case, many participants did not particularly change their eating habits. In fact, $65 \%$ of those who claimed they are very much in favor of paying attention to the environment consume multiple dairy products, compared to $76 \%$ of those who do not believe that the production of milk and dairy products is linked to environmental impact.

The merging of environmental and animal advocacy dimensions is strongly criticized in the literature because environmental theses focus too much on animal well-being and forget animal rights and animal liberation (Bertuzzi, 2020; Faria \& Paez, 2019). However, in the netnographic observations of the three 'no-milk' websites, we found that the environmental and animal rights theses share common attention towards ethically responsible consumption. We grouped together environmental and animal advocacy items in what we called an 'Index of Environmental Ethical Consumerism'. Those who pay particular attention to ethical consumerism represent $24 \%$ of the respondents - a minority, but nevertheless one out of four in our sample.

Ethical concerns pose little impact on consumption behavior (Table 2). In fact, $65 \%$ of those who possess ethical concerns regarding milk consumption ingest many or all dairy products as opposed to $75 \%$ who possess no or little interest in environmental and/ or ethical consumerism. There is, therefore, a reduction in the type of consumption that yet nonetheless concerns a small portion of consumers.

Even when we look at milk consumption alone (Table 4), merely $28 \%$ of those who do not consume milk are very sensitive to this ethical dimension, compared to $19 \%$ of 
Table 2. Interest in environmental, ethical consumerism and consumption of milk and dairy products.

\begin{tabular}{llllll}
\hline \multirow{2}{*}{$\begin{array}{l}\text { Interest in environmental, } \\
\text { ethical consumerism }\end{array}$} & \multicolumn{4}{l}{ Consumption of milk and dairy products } & \\
\cline { 2 - 6 } & Nothing & Few & Fairly & All & N \\
\hline No/A little & $12 \%$ & $13 \%$ & $29 \%$ & $46 \%$ & 288 \\
Yes/Very & $21 \%$ & $14 \%$ & $31 \%$ & $34 \%$ & 90 \\
\hline
\end{tabular}

those who do consume milk. Therefore, the decrease in milk consumption does not seem to be linked to a greater respect for animals, the earth, sustainability, or, broadly speaking, the environment.

Looking at the correlation between the index of environmental ethical consumption and the patterns of dairy consumption, we observe no strong correlation (Pearson's $\mathrm{R}=-0.1989$ ). Consumption behavior does not seem to be strongly influenced by ethical concerns, and the first hypothesis that emerges in the literature has been falsified by our data.

\section{Explaining change 2: A drop of milk and dairy consumption due to a perception of health at risk?}

The second hypothesis states that dairy consumption depends upon the perception of lactose-based products as threats to human health. Thus, if the hypothesis is verified, we expect to observe a strongly negative correlation between a perception of milk as dangerous to human health, on one side, and dairy consumption on the other. Having or believing one has allergies and/or a lactose intolerance would imply a reduction in dairy use.

In order to understand the perceived dangers of lactose-based products, we questioned whether any digestive problems are linked to the consumption of dairy products. Those who claimed they have no problem with milk and dairy products represent $63 \%$ of respondents, compared to $27 \%$ who claimed they have digestive problems and have accordingly decreased their consumption of milk and all dairy products. In our sample, $9 \%$ of respondents are lactose intolerant and $1 \%$ declared to be allergic to milk proteins. Overall, those who claimed to have problems with milk and dairy intake constitute $37 \%$ of the sample. Of those who claimed they feel uncomfortable, $56 \%$ claimed they have not and/or would not visit a doctor, compared to $44 \%$ who claimed they already have done or are willing to do so.

To go further in-depth by exploring interviewees' health concerns and health self-perceptions, we have analyzed two specific items: (1) 'animal milk is a necessary food in all age groups' and (2) 'calcium should be taken from other foods than milk and dairy products'.

The first item is rejected on websites that try to boycott the consumption of milk and dairy products. They contrast with the idea that milk is a necessary food, claiming there is no need to consume animal milk because babies may sufficiently consume breast milk until weaned. Afterwards, according to these movements, milk consumption is not only unnecessary, but it can pose negative health impacts ${ }^{2}$. After the net-ethnography, physicians told us during the interviews that their patients frequently share this belief. 
Table 3. Milk and dairy product consumption and the agreement that milk is a necessary food for every age.

\begin{tabular}{lllr}
\hline Milk and dairy product & \multicolumn{4}{l}{ Milk is a necessary food for every age } \\
\cline { 2 - 4 } consumption & Not at all/A little & Fairly/Very & $\mathrm{N}$ \\
\hline Yes & $59 \%$ & $41 \%$ & 324 \\
No & $80 \%$ & $20 \%$ & 54 \\
\hline
\end{tabular}

Table 4. Milk consumption and agreement that milk is a necessary food for all age groups.

\begin{tabular}{llll}
\hline Milk consumption & \multicolumn{2}{l}{ Milk is a necessary food for all age groups } \\
\cline { 2 - 4 } & Not at all/A little & Fairly/Very & $\mathrm{N}$ \\
\hline Yes & $48 \%$ & $52 \%$ & 184 \\
No & $74 \%$ & $26 \%$ & 194 \\
\hline
\end{tabular}

The second item focuses on another thesis found in netnographies recognizing the high calcium content in dairy products but simultaneously claiming calcium is healthier to ingest from other foods (e.g., broccoli, spinach) or from integrators.

With regard to the first item, $62 \%$ of respondents do not consider milk a necessary food for all age groups, while more than $21 \%$ strongly disagreed. Among those who do not consume any dairy products, $80 \%$ are not at all or only partially convinced that milk is a necessary food for both babies and all ages throughout the life cycle. This implies that even if the past governments and international organizations have promoted long campaigns to recognize milk as an essential food for healthy development, and while in 2001 they have institutionalized the World Milk Day (1st of June), the worth of milk is no longer recognized by highly educated young people. As a consequence, in the future, it will be more difficult to assess milk as a healthy food. This item also divides those who consume milk and dairy products, $59 \%$ of whom do not consider dairy products necessary foods (Table 3). There appears to be significant skepticism towards the benefits derived by the consumption of milk not only between people who are no longer consumers of milk and dairy products, but also between the overall consumers.

As expected, milk consumers exclusively believe the product is necessary, but the convincement between this population is quite insignificant, at a mere $52 \%$. The thesis that milk is not a necessary food outside childhood and the early portion of the developmental age range has become extremely pervasive among young consumers. Milk is the real scapegoat for what is happening in the dairy chain due to its intrinsic characteristics, such as its greater presence of lactose and therefore its greater probability of causing digestive problems. At the same time, Italian youth no longer recognize the potential for wellness and health that was attributed to milk in the past. And this is shared by both those who do not consume dairy products and those who habitually consume them (Table 4).

The second item, supported by no-milk movements and always concerning the health sphere, dictates that calcium is necessary for development but that, in reality, it is not 
Table 5. Milk and dairy product consumption and the agreement on the necessity to ingest calcium from other foods.

\begin{tabular}{lllr}
\hline Milk and dairy product & \multicolumn{2}{l}{ Necessity to ingest calcium from other foods } \\
\cline { 2 - 4 } consumption & Not at all/A little & Fairly/Very & $\mathrm{N}$ \\
\hline Yes & $43 \%$ & $57 \%$ & 324 \\
No & $65 \%$ & $35 \%$ & 54 \\
\hline
\end{tabular}

required that calcium be derived from milk or other dairy products; rather, it is more healthy when calcium is ingested from vegetal foods. $54 \%$ of respondents did not agree with this item, while $65 \%$ of those who do not consume dairy products agreed. $53 \%$ who do not drink milk agreed, compared to $38 \%$ of those who do drink milk (Table 5). Compared to the item related to milk's uselessness to adults, the answers concerning non-animal calcium intake widen our understanding of youth attitudes. The relevant polarization is that between those who ingest milk and dairy products and those who do not; this is a much more important division into two sharply contrasting groups with different sets of opinions and beliefs. The division in patterns of mere milk consumption is less important and divisive because many people who do not drink milk do not possess significantly different attitude structures than those who do drink milk. The cleavage passes from butter, yoghurt, and cheese use, but only concerning attitudes towards calcium assumption. Calcium is portrayed as a positive protein necessary for physical development. Its importance is not issue-related but it is connected with broaden and deepen attitudes towards health perception and well-being.

To understand if and how health concerns are considered in dietary choices, we have created an 'Index of Health Perception' based on two variables: (1) 'animal milk is a necessary food in all age groups' and (2) 'calcium should be taken from other foods than milk and dairy products'. We have polarized the variables to obtain a univocal directionality and introduced four modalities in the index: (1) not at all interested, (2) slightly, (3) fairly, and (4) very interested. We have aggregated the modalities to dichotomize the index and make it more readable. The Pearson Correlation Index between the Index of Health Perception and the variable of milk and dairy consumption is 0.3459 . In this case, the correlation index is higher than that in the Index of Ethical Consumerism although still quite low. The Pearson correlation coefficient measured in absolute value varies between -1 and +1 , reaching +1 in the case of a perfect, direct (increasing) linear relationship (correlation). Values approaching 0 establish that the two variables are closer to being uncorrelated, while a value above 0.3 can be considered indicative of a moderate correlation. In reality, $79 \%$ of respondents who are not worried about the health dimension eat several or all dairy products, while the $66 \%$ who achieved a high score in the Index of Health Perception exhibit similar consumption patterns (Table 6).

Our data reveal that, regarding the health perception, milk consumption is more important than the consumption of any dairy product. In fact, $64 \%$ of respondents who are very cautious of their health do not consume milk. This percentage drops to $34 \%$ among those who are not very interested in health issues. Milk consumption is directly affected by the health perception (Table 7). 
Table 6. Health Perception Index on milk and dairy product consumption.

\begin{tabular}{|c|c|c|c|c|c|}
\hline \multirow{2}{*}{$\begin{array}{l}\text { Milk and dairy product } \\
\text { consumption }\end{array}$} & \multicolumn{5}{|c|}{ Health Perception Index } \\
\hline & $\begin{array}{l}\text { Not at all } \\
\text { interested }\end{array}$ & $\begin{array}{l}\text { A little } \\
\text { interested }\end{array}$ & $\begin{array}{l}\text { Fairly } \\
\text { interested }\end{array}$ & $\begin{array}{l}\text { Very } \\
\text { interested }\end{array}$ & $\mathrm{N}$ \\
\hline Fairly/Everything & $21 \%$ & $13 \%$ & $29 \%$ & $37 \%$ & 186 \\
\hline Nothing /A little & $8 \%$ & $13 \%$ & $30 \%$ & $49 \%$ & 192 \\
\hline
\end{tabular}

Table 7. Health Perception Index on milk consumption.

\begin{tabular}{|c|c|c|c|}
\hline \multirow[t]{2}{*}{ Milk consumption } & \multicolumn{3}{|l|}{ Health Perception Index } \\
\hline & $\begin{array}{l}\text { Not at all interested/A } \\
\text { little interested }\end{array}$ & $\begin{array}{l}\text { Fairly interested/ } \\
\text { Very interested }\end{array}$ & $N$ \\
\hline No & $36 \%$ & $64 \%$ & 194 \\
\hline Yes & $66 \%$ & $34 \%$ & 184 \\
\hline
\end{tabular}

It is true that, for the item regarding the necessity to ingest calcium from foods other than milk, the difference occurred between those who consume dairy products and those who do not; however, regarding the health index, the relationship between the consumption and non-consumption of milk is comprehensively more powerful.

Health concerns have been revealed as strongly influencing milk consumption behavior. The second hypothesis that emerges in the literature has been partially verified by our data. The item concerning the need to consume calcium from foods of vegetable origin divides those who consume or do not consume dairy products in general. However, putting together the items that consider the health dimension, milk is the first food to not be considered healthy during adulthood.

\section{Trust and (dis)trust in medical expertise}

A moderate correlation between health concern and dietary choice creates space for exploring the sources of expertise Italian youth trust when making health-related decisions. What sources of information do they look at to understand the consequence of a specific dietary regime? And, to go beyond the 'why' question, how do they decide to stop drinking milk in particular and/or eating dairy products in general? Do they ask their general practitioners for counseling and guidance? What do they have faith in: their capacity to self-diagnose their body signs and self-determine their needs or, on the contrary, evidence-based medicine and dedicated screenings? What do they rely on, their family doctor's diagnosis, the opinions of friends and acquaintances, specific conferences and meetings organized by activists, or readings made while surfing the web?

Those who declare they experience some kind of problem with lactose are referring to digestive problems; half went to a physician for counseling, while the other half declared they were not inclined to visit a doctor. We can argue that this constitutes a large 
percentage of youth who do not fancy medical expertise. Those survey respondents who self-diagnosed allergies or intolerances do not consider general practitioners as unreliable or as paid off by the milk lobby; rather, they simply argue that they do not need medical expertise to take care of their health. It is fair to admit that, if Italian youth do not consult family doctors, our qualitative interviews reveal that general practitioners often do not appear to be particularly informed. Some doctors revealed a rather ambivalent position with respect to the benefits of milk and dairy products as well as a lack of awareness of the World Health Organization (WHO) guidelines on the subject. In fact, in our interviews, we were able to determine that all doctors consider milk - whether it be maternal or animal - as being fundamental for humans from two to three years of age. All doctors recognize the importance of milk's calcium content until the end of human development, but some possess a rather less clear position on ingesting milk and an even less precise position on milk and dairy consumption by adults. During the interviews, in many cases, physicians told us they tend to advise in favor of dietary restrictions rather than specific tests and screenings.

Indeed, many people feel a sense of discomfort that does not directly translate into an allergy or intolerance. We inquired about allergies to lactose or milk proteins in addition to a possible sense of discomfort when consuming milk and dairy products. Allergies can have important consequences however, if the European Food Safety Authority has certified that, in Europe, up to $56 \%$ of the adult population may have a lactase deficiency (or lactase non-persistence), this does not imply they should avoid milk and dairy products because these products remain essential for the appropriate intake of calcium (EFSA, 2010). The decision to stop consuming is not particularly influenced by vegan movements or no-milk campaigns, which are considered only minor influencers. Facing eventual discomfort, Italian youth do not look for medical expertise, systematic screenings, or evidence-based advice on an appropriately healthy diet. For instance, they decide to stop drinking milk and eating mature cheeses but continue bolting down mozzarella, which is perceived as a light cheese. Regarding consumption choice, price, ingredients, and origin are the three factors our interviewed youth consider, while quality and/or organic certification received much lower scores. Looking at our sample of highly educated youth, 50\% simply ignore medical expertise when making dietary choices. Milk and dairy products are equated with unhealthy, fatty foods. Furthermore, most respondents who declared digestive problems as being the reason for adapting their dietary regimes do not altogether avoid consuming dairy products. $51 \%$ of youth regulate their dairy use by putting an end to consuming milk, entangling this choice with the continuous consumption of other products, and introducing non-animal 'milk' into their diets. The result is that consumers are not informed that they may still consume a moderate amount of milk (EFSA, 2010). In our opinion, because they don't recognize anymore the benefits of milk, they don't seek advice from doctors or from any source of medical expertise, which is evident in respondents who claimed they do not consider this product necessary for all age groups. This result is not related to the theses of movements that are critical to the consumption of milk and dairy products. Vegan ideas are known only by a small number of respondents; however, we argue that this is linked with the previous decades that have claimed children and adolescents benefit more from milk than do adults (Cohen, 2017; Daftary, 2019). Self-diagnosis plays a major role, and general practitioners are not essential figures for guidance in dietary decision-making. 


\section{Individualism, mistrust in medical expertise, and youth healthy consumerism}

Throughout the 20th century, milk became the target of many campaigns for a more sustainable and healthy lifestyle. However, in the opposite direction, progressive movements began mobilizing during the early 21 st century on a global scale in an effort to redistribute the opportunity to drink milk. Later, we assisted to the spread of a new and innovative no-milk campaign.

Milk studies have produced relevant results on political, symbolic, and semantic dimensions for dairy consumption. Our paper aims not to challenge previous results, but rather to highlight some not-yet explored points. Thus, our purpose is not to merge marketing studies with a more traditional, constructivist approach to milk nor to view them antagonistically, but rather to insist on the macro-sociological interpretation of our results.

The knowledge of anti-milk movements cultural impact (Amenta \& Polletta, 2019) is still very low worldwide. Literature has more studied these movements ideas, particularly among vegans, related to the externalities over the production and consumption of animal-based products (Bennett, 1995; Mayfield et al., 2007), more than their influence on people's opinions. Even if the literature tends to assume a sort of strategic depoliticization of these movements to have a larger cultural impact (Righetti, 2018), our interpretation points to the fact that there is a tendency in society that is not related with vegan movements narratives, but with a new framing of food as a potentially dangerous source of disease. This framing includes scripts related to food with animal origin but it goes well beyond it, including all kind of processed and fresh food. This culture of fear on food has never had political scripts and has never been related to some kind of mainstreaming strategy aiming to 'hide' political narratives for strategic reasons of cultural hegemony. ${ }^{3}$

The more strongly one believes milk is bad for their own health, the less frequently one consumes milk; unlike ethical issues, health concerns influence behavior, yet not to the point of one giving up cheese or butter-based sweets. As Gianfranco Bettin Lattes states, young people are a 'kaleidoscope' made of flexibility, reversibility, at the paradoxical intersection of inconsistent behaviors (Bettin Lattes, 2007). However, this does not mean that it is not possible to find reasons and rationality in their choices, as data reveal that highly educated young people seem to possess little awareness of the health implications of consuming or not dairy products. In people who do not consume dairy products and are not involved in vegan movements, we observe a very loose consistency between beliefs and behavior, but, on the contrary, a strong responsible reflexivity on personal health issues, and a selective (non-holistic) type of consumption, focused on the (negative) power of milk.

With regard to the ethical and environmental dimension, the fact that these issues have not strongly resonated with highly scholarized Italian youth does not mean that topics related to sustainable production and animal advocacy are not important in terms of hierarchical values or discourse topics' saliency during moments of sociability. Rather, our research contributes towards addressing these topics' relevance within the gap between attitudes and behaviors. Concerns about the ethical and environmental dimension does not directly influence the consumption of dairy products because the awareness paid to this dimension is low among consumers and because there exists a contradiction between attention paid to the environment and animal advocacy (Bertuzzi, 2018; Faria \& Paez, 2019). Broadly, the 
influence of no-milk mobilizations is very low and affects a narrow segment of youth consumers who have already decided to stop consuming any food of animal origin.

However, actors with this particular awareness act as political consumers, which means the politicization of consumption (Forno, 2018) is a classic example of an 'individualised collective action' (Micheletti \& McFarland, 2010; Bertuzzi, 2020), or networking participation, where public actions take place in private spaces or, depending on the case, private actions take place in public spaces (Papacharissi, 2011).

Our figures prove that the number of dairy non-users is low and is made by people who have abandoned dairy consumption rather than people who have never consumed dairy. The main reason for their abandonment is that they have experienced digestive problems. However, when this problem arises, they generally have no motive to visit a doctor. Here, 'motive' represents the deep sociological sense proposed by Charles Wright Mills (1940) rather than a merely individual preference - an available justification for assessing actions as well as the meanings and expectations surrounding these actions' possible consequences.

Family doctors do not seem to provide valid motives for being sought for counsel regarding dietary restrictions. A very strong propensity for disintermediate health and dietary choice emerges from our data concerning half of those well-educated youth in need of understanding a physical discomfort. As an example, digestion problems seem to confirm consumers' perceived lactose deficiency, and there's no need for them to look for alternative explanations or make a non-self-governed dietary regime with their family doctor. In the absence of medical expertise and intermediation, tautological cognitive mechanisms guide dietary choices, would it be for milk consumption or not.

We do not argue that young people mistrust science or medicine, but rather that they mistrust practitioners' competence on the link between food and health. Today, as was already the case at the beginning of the millennium, the low level of trust in experts who 'should be' worthy of trust remains a significant issue (O’Neill, 2002). Practitioners' low knowledge of nutrition is intertwined with weak communication skills, and this combination is filled with consequences regarding the youth perception of affordable and safe sources of counsel and expertise.

Italian educated youth mistrust towards medical expertise on milk ${ }^{4}$ goes along with new trends on healthy consumption, which have opened up room for a bigger and bigger market of X-free commodities (gluten-free, lactose-free, palm oil-free, and so on). The well-known importance of identity for understanding and interpreting youth consumption patterns has to be nuanced with an emerging trend, that of turning away from large corporations and buying craft and handmade products.

This is related to how youth beliefs are influenced by a strong expressive individualism, a self-taking care of proper health and a tendency to act not for political and ethical concerns, but for a claimed perceived well-being. In other words, what distinguishes veganism as a public claim of identity and the non-consumption of milk by the large majority of young educated people in our sample is not only a different evaluation of capitalism and animal rights but rather a different relation to consistency. Indeed, inside vegan movements, consistency has a 'tautological character', typical of institutionalized and elaborated cultures (Boltanski, 2011). At most, we have measured inconsistency, uncertainty, and the primacy of healthy consumerism on ethical consumerism within our 
sample. These youth use their education to surf within spare knowledge of self-health. Highly educated youth excel in critical competencies, deconstructing the knowledge of physicians as relative, situated, and rooted in a particularistic point of view. We can easily talk of a 'hermeneutical contradiction' (Boltanski, 2011) because those highly educated youth do not trust physicians, do not ask for their advice, but can still rely on a medical language, to look for their 'do it yourself' health and well-being.

Young people in Italy are suffering a severe condition of working precariousness and this results in the forced-choice of many among them to avoid medical visits except in the case of severe sickness (Caranci et al., 2016). 'Presentification' (Leccardi, 2014), uncertainty, and insecurity reduce structural opportunities and motivations to collective action (Alfieri et al., 2015), so that young people partly build their individual subjectivity without asking medical expertise and looking for a dialogue with their peers. Moreover, the familiarity of young people with digital tools suggests the choice of self-diagnosis, with all related risks. Taking care of yourself, following or not medical expertise, is not only a practice, but a form of subjectivation, and it enables to build your proper identity and to distinguish from others. Milk non-consumption also emerges as a new dimension to create your own status as observed towards vegan diet (Veron, 2016), constituting a cultural fact, or - to be more precise - a subcultural fact. Young people who do not drink milk and do not ask for medical advice on their dietary choices neither know nor trust narratives, frames and scripts coming from vegan movements. They make self-diagnosis, privilege health consumption over political consumerism for their identity and subjectivity, 'sail on sight' (Pirni \& Raffini, 2017), do not trust medical authorities and procedures, and follow hybrid, patchworked scripts related to what they hope, more than perceive, are non-harmful goodies and healthy nutrition.

\section{Acknowledgements}

The survey was designed by Rosalinda Bruno, Alice Gruppi of the Catholic University of the Sacred Hearth, Nerissa Fiorani, Luigi Ortolano, Martina Ragni, Michele Sogari, Alessandra Tamburriello and created by Niccolò Morelli of the Catholic University of the Sacred Hearth. We are thankful to members of the Osservatorio sui Consumi Alimentari that tested the questionnaire and helped for the qualitative interviews. The first edition of this survey was implemented in 2016 . It won the Second Prize at the Conference 'Universo Latte', Piacenza May 2017.

\section{Funding}

The author(s) received no financial support for the research, authorship, and/or publication of this article.

\section{ORCID iD}

Niccolo Morelli (iD https://orcid.org/0000-0001-8916-8640

\section{Notes}

1. The employment condition is closely related to the respondents' young age range. In fact, $86 \%$ of respondents aged between 18 and 24 years were students or student workers, while $56 \%$ of those aged between 25 and 30 were workers, with a considerable proportion of students 
still working (37\%). $4 \%$ of respondents aged between 18 and 24 were unemployed, while $8 \%$ aged between 25 and 30 were unemployed, which are significantly lower statistics than the national average for youth unemployment (32\%).

2. At the same time, we know that within the vegan movement there is an intellectual debate on the same opportunity of mobilising an indirect argument related to human health because it is believed to be too anthropocentric in its assumptions (Bertuzzi, 2018).

3. On the ordinary use of the concepts of narratives, frames, scripts and repertoires in cultural sociology, see Lamont and Small (2008).

4. People's mistrust of medical expertise and self-restriction towards dairy consumption reduce bodies tolerance towards lactose and they participate to the rising amount of people with lactose intolerance or at least of people living in the belief of having it (Zaitlin et al., 2013).

\section{References}

Alfieri S, Sironi E, Marta E, et al. (2015) Young Italian NEETs (Not in Employment, Education, or Training) and the influence of their family background. Europe's Journal of Psychology 11(2): 311-322.

Allès B, Baudry J, Méjean C, et al. (2017) Comparison of sociodemographic and nutritional characteristics between self-reported vegetarians, vegans, and meat-eaters from the NutriNetSanté study. Nutrients 9(9): 1023-1041.

Alteri L, Leccardi C, Raffini L (2016) Youth and the reinvention of politics. New forms of participation in the age of individualization and presentification. Partecipazione e conflitto 9(3): 717-747.

Amenta E, Polletta F (2019) The cultural impacts of social movements. Annual Review of Sociology 45:279-299.

Andersen SS, Holm L (2018) Naturalness as a safe haven: Parental consumption practices and the management of risk. Young Consumers 19(3): 296-309.

Armstrong P (2000) All things bold and beautiful: Researching adult learning through soaps. 41st Annual Adult Education Research Conference, Vancouver, Canada.

Atkins P (2010) Liquid Materialities. A History of Milk, Science and the Law. London: Routledge.

Bardhan P, Huria V (1987) Cost of milk production: Its relevance to pricing. In: Shah D (ed.) Milk Pricing and Marketing Practices of Cooperative Dairy Industry in Gujarat. Surat: Maricheemalee Prakashan, 88-100.

Bassoli M, Monticelli L (2018) What about the welfare state? Exploring precarious youth political participation in the age of grievances. Acta Politica 53: 204-230.

Bennett R (1995) The value of farm animal welfare. Journal of Agricultural Economics 46: $46-59$.

Bertuzzi N (2018) The animal advocacy archipelago and the four animalisms. Partecipazione $e$ Conflitto 11(3): 865-890.

Bertuzzi N (2019) The contemporary Italian animal advocacy. Modern Italy 24(1): 1-20.

Bertuzzi N (2020) The individualization of political activism: A reflection on social movements and modernization, starting from the case of Italian animal advocacy. International Journal of Sociology and Social Policy 40(3/4): 282-303.

Bettin Lattes G (2007) Prefazione. In: Bontempi M, Pocaterra R (eds) I figli del disincanto. Giovani e partecipazione politica in Europa. Milan: Bruno Mondadori, 9-16.

Biorcio R, Vitale T (2020) Learning democratic attitudes and skills: Politics and volunteer engagement. In Guidi R, Fonovic K, Cappadozzi T (eds) Accounting for the Varieties of Volunteering. New International Statistical Standards Tested in Italy. Berlin: Springer, 167-191. 
Bir C, Widmar NO, Wolf C, Delgado MS (2019) Traditional attributes moo-ve over for some consumer segments: Relative ranking of fluid milk attributes. Appetite 134: 162-171.

Boltanski L (1968) La Découverte de la maladie: la diffusion du savoir médical. Paris: Centre de sociologie européenne.

Boltanski L (2011) On Critique. A Sociology of Emancipation. Cambridge, UK: Polity Press.

Borgerson JL (2005) Materiality, agency, and the constitution of consuming subjects: Insights for consumer research. Advances in Consumer Research 32: 439-443.

Bowler GM (2010) Netnography: A method specifically designed to study cultures and communities online. The Qualitative Report 15(5): 1270-1275.

Caranci N, De Felici P, Giuliano G, et al. (2016) Utilizzo degli indici di deprivazione per orientare le politiche pubbliche di contrasto alla povertà. Nona Conferenza Espanet, Macerata, Italy, 22-24 September 2016. Available at: http://isfoloa.isfol.it/xmlui/handle/123456789/1329

Cicourel AV (1999) The interaction of cognitive and cultural models in health care delivery. In: Sarangi S, Roberts C (eds) Talk, Work and Institutional Order: Discourse in Medical, Mediation and Management Settings. Berlin: Mouton De Gruyter, 183-226.

Cohen M (2017) Regulating milk: Women and cows in France and the United States. The American Journal of Comparative Law 65(3): 469-526.

Cohen M, Otomo Y (eds) (2017) Making Milk: The Past, Present, and Future of our Primary Food. London: Bloomsbury.

Daftary D (2019) Market-driven dairying and the politics of value, labor and affect in Gujarat, India. The Journal of Peasant Studies 46(1): 80-95.

Delgado CL (2003) Rising consumption of meat and milk in developing countries has created a new food revolution. The Journal of Nutrition 133(11): 3907S-3910S.

Doxa-Aidepi (2015) Quando nasce la colazione italiana? Un salto negli anni '50. Available at: http://iocominciobene.it/quando-nasce-la-colazione-italiana-un-salto-negli-anni-50/ (accessed 9 February 2019).

DuPuis M (2002) Nature's Perfect Food: How Milk Became America's Drink. New York: NYU Press.

EFSA (2010) Scientific opinion on lactose thresholds in lactose intolerance and galactosaemia. Efsa Journal 8(9): 1777-1806.

Enticott G (2003) Risking the rural: Nature, morality and the consumption of unpasteurised milk. Journal of Rural Studies 19(4): 411-424.

Eurispes (2017) Rapporto Italia 2017. Bologna: Minerva Edizioni.

Eurispes (2018) Vegani e vegetariani sono il 7\% della popolazione dai 18 anni in su. Available at: https://eurispes.eu/news/eurispes-rapporto-italia-2018-vegani-e-vegetariani-sono-il-7-dellapopolazione-dai-18-anni-in-su/ (accessed 26 February 2019).

Faria C, Paez E (2019) It's Splitsville: Why animal ethics and environmental ethics are incompatible. American Behavioral Scientist 63(8): 1047-1060.

Forno F (2018) Protest, social movements, and spaces for politically-oriented consumerist actions - Nationally, transnationally, and locally. In: Boström M, Micheletti M, Oosterveer P (eds) The Oxford Handbook of Political Consumerism. Oxford: Oxford University Press, 69-88.

Gerrior S, Putnam J, Bente L (1998) Milk and milk products: Their importance in the American diet. Food Review/National Food Review 21: 29-37.

Harman V (2018) The Italian breakfast: Mulino Bianco and the advent of a family practice (19711995). European Journal of Marketing 52(12): 2478-2498.

Harmon A (2018) Why white supremacists are chugging milk (and why geneticists are alarmed). New York Times, 17 October. 
Idan E, Xing A, Ivory J, et al. (2020) Sociodemographic correlates of medical mistrust among African American men living in the East Bay. Journal of Health Care for the Poor and Underserved 31(1): 115-127.

Inaudi S (2018) Milk is life: Nutritional interventions and child welfare: The Italian case and post-war international aid. In: Gentilcore D, Smith M (eds) Proteins, Pathologies and Politics Dietary Innovation and Disease from the Nineteenth Century. London: Bloomsbury, 149-160.

Ismea (2017) XIV Rapporto 2016 sulle produzioni agroalimentari e vitivinicole italiane DOP IGP STG.

Istat (2018) Available at: https://www.istat.it/it/archivio/demografia

Jones DS (2017) Patients, consumers, and the enduring challenge to medical authority. Reviews in American History 45(1): 128-135.

Kamana O, Ceuppens S, Jacxsens L, et al. (2014) Microbiological quality and safety assessment of the Rwandan milk and dairy chain. Journal of Food Protection 77(2): 299-307.

Kozinets RV (2010) Netnography. Doing Ethnographic Research Online. Thousand Oaks, CA: Sage.

Kristensen DB, Boye H, Askegaard S (2011) Leaving the milky way! The formation of a consumer counter mythology. Journal of Consumer Culture 11(2): 195-214.

Lamont M, Small ML (2008) How culture matters for the understanding of poverty: Enriching our understanding. In: Lin AC, Harris DR (eds) The Colors of Poverty: Why Racial and Ethnic Disparities Persist. New York: Russell Sage Foundation, 76-102.

Leccardi C (2014) Young people and the new semantic of the future. SocietàMutamentoPolitica 5(1): 41-54.

Le Pape MC, Plessz M (2017) C'est l'heure du petit-déjeuner? Rythme des repas, incorporation et classe sociale. L'Année sociologique 67(1): 73-105.

Mattozzi A, Piccioni T (2012) A depasteurization of Italy? Mediations of consumption and the enrollment of consumers within the raw-milk network. Sociologica 3.

Mayer N (2018) The political impact of social insecurity in France. Partecipazione e Conflitto 11(3): 646-691.

Mayfield LE, Bennett RM, Tranter RB, et al. (2007) Consumption of welfare-friendly food products in Great Britain, Italy and Sweden, and how it may be influenced by consumer attitudes to, and behaviour towards, animal welfare attributes. International Journal of Sociology of Food and Agriculture 15(3): 59-73.

Mendelson A (2008) Milk. The Surprising Story of Milk Through the Ages. New York: Alfred A. Knopf.

Micheletti M (2003) Political Virtue and Shopping. Individuals, Consumerism, and Collective Action. London: Palgrave Macmillan.

Micheletti M, McFarland A (2010) Creative Participation: Responsibility-Taking in the Political World. Boulder: Paradigm Publisher.

Mills CW (1940) Situated actions and vocabularies of motive. American Sociological Review 5(6): 904-913.

Montini L (1957) Introduzione. In: Istituto Nazionale della Nutrizione, Amministrazione per le Attività Assistenziali Italiane ed Internazionali (eds) Il latte alimento per tutti nel pensiero di fisiologi, igienisti e clinici italiani. Roma: Garzanti, 16.

Moon E (2018) Why is milk being called a white supremacist symbol? Pacific Standard 24(10).

Morel N, Palier B, Palme J (2012) Towards a Social Investment Welfare State? Ideas, Policies and Challenges. Bristol: Policy Press.

Morris C, Mylan J, Beech E (2019) Substitution and food system de-animalisation. The International Journal of Sociology of Agriculture and Food 25(1): 42-58.

Mouat M, Prince R (2018) Cultured meat and cowless milk: On making markets for animal-free food. Journal of Cultural Economy 11(4): 315-329. 
NDDB (1977) Operation Flood II: A Proposal. Anand, Gujarat: National Dairy Development Board.

Nichols T (2017) The Death of Expertise. The Campaign Against Established Knowledge and Why it Matters. Oxford: Oxford University Press.

Nielsen SJ, Popkin BM (2004) Changes in beverage intake between 1977 and 2001. American Journal of Preventive Medicine 27(3): 205-210.

O'Neill O (2002) A Question of Trust: The BBC Reith Lectures 2002. Cambridge: Cambridge University Press.

Pagliai L (2010) Giorgio La Pira e il 'piano latte'. La funzione sociale della Centrale. Florence: Edizioni Polistampa.

Papacharissi Z (ed.) (2011) A Networked Self. Identity, Community, and Culture in Social Network Site. London: Routledge.

Pirni A, Raffini L (2017) The ri-elaboration of the collective sphere. New paths of sociality and groups-formation among the new generations. Partecipazione e Conflitto 9(3): 799-823.

Polizzi E, Tajani C, Vitale T (2013) Programmare i territori del welfare. Attori, meccanismi ed effetti. Roma: Carocci Editore.

Righetti N (2018) Il veganismo tra mainstream e controcultura. Micro \& Macro Marketing 27(1): $109-130$.

Sabban F (2014) The taste for milk in modern China (1865-1937). In: Klein JA, Murcott A (eds) Food Consumption in Global Perspective. Consumption and Public Life. London: Palgrave Macmillan, 182-208.

Sandlin JA (2007) Netnography as a consumer education research tool. International Journal of Consumer Studies 31: 288-294.

Schluchter W (1986) Modes of authority and democratic control. In: Meja V, Stehr N, Thisgeld D (eds) Modern German Sociology. New York: Columbia University Press, 291-323.

Terhal P (1987) The optimal management of milk grid system. In: Shah D (ed.) Milk Pricing and Marketing Practices of Cooperative Dairy Industry in Gujarat. Surat: Maricheemalee Prakashan, 166-179.

Tosi S, Vitale T (2008) Responsabilité directe. Hybridations croisées entre catholiques et laïcs dans les mouvements pour la paix en Italie. In: Sommier I, Fillieule O, Agrikolianky E (eds) La Généalogie des mouvements antiglobalisation en Europe. Paris: Karthala, 187-206.

Tosi S, Vitale T (2009) Explaining how political culture changes: Catholic activism and the secular left in Italian peace movements. Social Movements Studies 8(2): 131-147.

Turina I (2018) Pride and burden: The quest for consistency in the anti-speciesist movement. Society \& Animals 26(3): 239-258.

Turina I (2019) An interpretive account of individual, nonviolent radicalization. Humanity \& Society 43(3): 250-269.

Veron $\mathrm{O}$ (2016) (Extra)ordinary activism: Veganism and the shaping of hemeratopias. International Journal of Sociology and Social Policy 36(11/12): 756-773.

Vitale T (2003) Abbassare la soglia: confini ed apprendimento. In: Bifulco L (ed.) Il genius loci del welfare. Strutture e processi della qualità sociale. Rome: Officina, 136-49.

Weber M (2019) Economy and Society. Cambridge, MA: Harvard University Press.

Williamson LD, Bigman CA (2018) A systematic review of medical mistrust measures. Patient Education and Counseling 101(10): 1786-1794.

Wright L (2019) Milking the Zeitgeist. HUMaNIMALIA 10(2): 250-255.

Zaitlin P, Dwyer J, Gleason GR (2013) Mistaken beliefs and the facts about milk and dairy foods. Nutrition Today 48(3): 135-143.

Zamagni V (1998) L'evoluzione dei consumi tra tradizione e innovazione. In: Storia d'Italia: Annali 13. L'Alimentazione. Turin: Einaudi, 171-204. 


\section{Author biographies}

Niccolò Morelli is Post-Doc Researcher in Sociology at Catholic University of the Sacred Hearth, Milan where is part of the Osservatorio Giovani Sud, a research lab on the Southern youth condition. He is also Adjunct Professor of General Sociology at Padua University. He has recently published an interview in Sociologia (2020) with Robert J. Sampson on the main challenges for urban sociologists.

Tommaso Vitale is Associate Professor of Sociology at Sciences Po in Paris where he is the scientific director of the Master 'Governing the large metropolis', a researcher at Centre d'études européennes et de politique comparée, and a member of the research program 'Cities are back in town'. His main research fields are comparative political sociology and comparative urban sociology. 